\title{
AFTER THE AFGHAN WAR: NATIONALISM AND THE CHANGES IN THE BALANCE OF POWER IN CENTRAL ASIA
}

\author{
Ariel Cohen, Ph.D.(USA)
}

The military necessities of the war in Afghanistan dictated the renewal of American interest and involvement in Central Asia. As the United States faced the challenge of a speedy power projection into the main front against the Taliban in the north, U.S. policy makers turned to Central Asian states and Russia. In a short time - three to four weeks, the National Security Council, the U.S. military and the U.S. Department of State were able to secure facilities to resupply the Northern Alliance, and to pre-position aircraft and technical crews.

From the end of September 2001, the U.S. started deploying Special Forces in the countries adjacent to Afghanistan and moves them into the Northern Alliance territory. Considering difficulties of access, sluggish pace of diplomatic relations prior to $9 / 11$, the lack of modern air bases, and sheer distances, this was a coup of U.S. policy.

However, successful power projection of a global superpower raises new issues, especially with regards to the attitude of regional powers to American presence. In addition, while much was about American global power aspirations, the reality is different. What is the actual American presence in Central Asia and how much does it change the balance of power in the region? How will it affect the future of Central Asia - all these questions are awaiting their answers.

\section{America's Challenge}

Since the fall 2001, the U.S. projected elements of air power and Special Forces into Central Asia. According to General Richard Myers, the Chairman of the Joint Chiefs of Staff, An U.S. and NATO air force base was established in Manas International Airport, Kyrgyzstan, and Qarshi Khanabad, Uzbekistan. ${ }^{1}$ some of these deployments came under the aegis of NATO and Partnership for Peace program, while others through bilateral U.S.-Uzbekistan military contacts. ${ }^{2}$ General Anthony Zinni, then-CINC of the Central Command, which is geographically in charge of Central Asia, has started these contacts in the late 1990s.

${ }^{I}$ DOD News briefing, part 2 of 2, M2 Press wire, February 22, 2002.

${ }^{2}$ DoD News briefing, February 22. 
While these units have an immediate relevance to the war in Afghanistan, civilian public servants, the military, and analysts in the Pentagon and beyond have suggested that some of these units may be of use in the future action against terrorist organizations and regimes which support them. Off the record, the Pentagon officials have said that while the U.S. has not requested permanent basing rights in the region, its presence will be open-ended. ${ }^{3}$ U.S. policy makers and officials have suggested different avenues of rationalization for the current and future presence. They named protecting energy resources and pipelines; deterring the resurrection of Islamic fundamentalism in Central Asia; preventing Russian and/or Chinese hegemony; facilitating democratization and market reforms; and using Central Asia as a re-supply depot for possible action in Afghanistan, as preferred rationale for U.S. presence. Moreover, Central Asia was mentioned as a launching pad in the future operations against Iraq and Iran. ${ }^{4}$ It will be shown below that most of these explanations are insufficient by themselves; however, it is possible that a combination of such policies does require at least a modest level of the U.S. military and political presence in the region.

Since the beginning of the war, bilateral contacts with Russia and Central Asian -states grew in both frequency and intensity. The Deputy Secretary of State Richard Arbitrage- Russian Deputy Foreign Minister Vyacheslav Trubnikov working group on counter-terrorism expanded its purview to include the war on terrorism and Afghanistan. A high quality exchange of intelligence was instituted between the Russian and American intelligence communities - an unparalleled achievement which goes even beyond the precedent of World War Two, when two countries' intelligence establishments viewed each other with extreme mistrust.

U.S. diplomatic activity in the region is on the rise. In late January 2002, a delegation co-chaired by Elizabeth Jones, Assistance Secretary of State for European and Eurasian Affairs and Mira Ricardo, Deputy Assistant Secretary of Defense for Eurasia visited Tashkent for the fist U.S. - Uzbekistan Joint Security Cooperation Consultations (JSCC). The delegation also visited Kazakhstan, Kyrgyzstan, Tajikistan and Turkmenistan. ${ }^{5}$

The US government has put the best face possible on Uzbek President Islam Karimov's visit to Washington in March. Officials from the State Depart-

${ }^{3}$ Personal interviews with the Pentagon officials, who requested anonymity, March 2002, Washington, D.C

${ }^{4}$ Ibid

${ }^{5}$ First U.S.-Uzbek Security Consultations," Kabar News Agency of Kyrgyzstan, January $29,2002$. 
ment, National Security Council and the Pentagon stress that Karimov promised to improve Uzbekistan's human rights record, adding that they believe Karimov is sincere in his desire to promote civil society in the Central Asian nation.

Karimov ended his US visit on March 14 with several stops in New York, including a brief visit to the downtown site where the World Trade Center buildings once stood. The same day in Washington, officials gave Karimov's performance high marks at a not-for-attribution briefing. The Uzbek leader has faced widespread criticism in recent years for a crackdown on basic rights in Uzbekistan. But Bush Administration officials insisted that Karimov recognized domestic rights conditions in Uzbekistan needed to improve. The Uzbek leader also admitted that his government had to relinquish total control over the economy.

"He is not stupid," one US official said. "He delivered a surprisingly intelligent speech to the business community; and his remarks to President Bush were quite sincere - unless he deserves an Oscar for acting."

Some advocates have worried that by stepping up aid to Uzbekistan after joining the war on terrorism, the United States would reward Karimov's repressive rule. One official, speaking on background, disputed that notion. "He understands that he has a problem with human rights, and he openly said so. He owes the United States his security, if not his survival," the official said. "I don't think he will string us on and lead us by the nose."

Karimov certainly seemed humbled, according to note-takers, at his meetings with President George W. Bush and Secretary of State Colin Powell. The Uzbek leader repeatedly voiced appreciation for the Americans' respectful and low-key tone, say government officials with knowledge of the meetings. Karimov gave a clear-cut promise to "improve behavior" in the future.

"If only anyone explained these things to me this way before," Karimov reportedly lamented, "we would be along the way to implement these reforms... These issues are our responsibility. We will follow through on what we signed. I understand that Uzbekistan needs it, not the United States."

US officials said both Bush and Powell stressed to Karimov that without significant improvements on human rights and economic liberalization, the US Congress will not be receptive to further allocations of economic and security assistance.

US officials suggest that Karimov has already moved to fulfill his pledge to improve the country's democratic climate. Prior to arriving in Washington, the Uzbek government registered a human rights organization, and released over 800 political prisoners from prison. Human rights organizations have praised Karimov's recent moves, but say they alone do not comprise a liberalization trend. 
Karimov's actions follow a big increase in American aid. In the current supplemental 2002 US assistance budget, Uzbekistan is about to receive over $\$ 155$ million - \$83.5 million above the aid allocated prior to the September 11 attacks. The US Export-Import Bank also inked a fresh $\$ 55$ million credit facility for small and midsize Uzbek businesses during Karimov's visit. About one-half the aid total will consist of security assistance, including communications gear for the Uzbek military and programs aimed specifically at improving border patrols. The remaining half of aid would be devoted to a wide variety of socioeconomic areas, including programs to combat the spread of HIV/AIDS, the environmental rehabilitation of the Aral Sea basin, and improvements in social services in the Ferghana Valley.

In Washington, Karimov also reached out to the international financial institutions, such as the World Bank and the International Monetary Fund (IMF), after repeatedly snubbing these organizations' advice for years. The IMF closed its offices in Uzbekistan in 2001, citing frustration over the Karimov government's reluctance to carry out essential reforms, including the convertibility of the local currency, the some.

The Bush Administration officials who deal with Uzbekistan on a daily basis understand that they must pursue human rights and political liberties in the name of security. Without security, there will be no investment; but without investment, there will be no economic development. However, they also stressed that in the middle of the war on terrorism, security takes the front seat.

Karimov remains concerned about national security and in Washington held meetings with top defense department officials. Indeed, the centerpiece of his visit was the signing of a Declaration of Strategic Cooperation. The Pentagon has taken a lead in cooperating, training and supplying the Uzbek military. Despite the rumored death of Islamic Movement of Uzbekistan leader Juma Namangani during the anti-terrorism campaign in Afghanistan, Karimov is anxious to keep building the Uzbek military's capacity.

Even if the IMU cannot reconstitute, Hizb-ut-Tahrir, a radical Islamist party, which advocates the overthrow of Karimov's regime, could help foment antigovernment unrest. The Strategic Cooperation pact includes a promise by Americans to "regard with grave concern any external threat" to the Uzbek government. ${ }^{6}$ Hizb-ut-Tahrir already causes grave concern both for the Karimov regime and for the US government, American diplomats stressed.

6 Elaine Monaghan, "Bush Treads Fine Line as He Thanks Uzbek Leader," Reuters News English, 12 March 2002, 20:14. 
Because of these concerns, some in the US human rights community recognize that in order to pursue specific liberalization measures, or to get notorious cases of persecution reversed, it may be worthwhile to work through the Pentagon. "The US military has a unique channel of communication with the Karimov regime," says one congressional staff member who is deeply involved in promoting democracy in Uzbekistan.

However, the Pentagon is primarily focused on future geopolitical engagement in Uzbekistan, irrespective of the human rights climate. In their meeting, Karimov and Secretary of Defense Donald Rumsfeld discussed the future of American bases in Central Asia. The US government's official position is that it does not seek permanent bases in Central Asia. At the same time, officials say they want access to former Soviet facilities for an indefinite period - at least as long as the war on terrorism is continuing. Such a formula is vague enough to keep everyone in the region nervous, but it avoids a direct clash with Russia over regional spheres of influence. In October 2001 Russia requested - and conducted -consultations with the United States over the future of Central Asia. The second round of consultations will take place in Moscow in April.

According to sources present at Karimov's talks with Buslv^owell and Rumsfeld, the Uzbek ruler's main worry - and warning - was about Iranian meddling in Afghanistan. Karimov apparently believes that Tehran will try to undermine stability there by exploiting centuries-old ethnic rivalries, in order to undermine the United States and its allies. If that scenario were to materialize, the United States would need to act as a more solicitous friend to players throughout the region, including Karimov himself. As one American diplomat said, "If you thought politics make strange bedfellows, try war - it makes stranger ones. ${ }^{7}$

It looks like Uzbekistan will become a centerpiece of American policy in the region, but engagement in other countries, and especially Kazakhstan, with its giant energy resources, is also in the cards.

\section{Russia adapts to the New Reality}

After the 9/11 attack, President Putting has directed Russia along the new path -that of acquiescence, if not acceptance, of the open-ended U.S. presence in the region. He convinced his Defense Minister Sergey Ivan, to reverse himself on opposition to the NATO use of Central Asian military bases. Whereas Ivan had a legal basis to oppose such use in cases of Tajikistan and Kyrgyzstan,

${ }^{7}$ Ariel Cohen, "US Officials give high marks to Karimov on Washington Visit," Eurasia Insight, March 18, 2002, http://www.eurasianet.org/departments/insight/articles/ eavO315O2b.shtml 
both countries members of the Commonwealth of Independent States (CIS) Collective Security Treaty, he had no such grounds in case of Uzbekistan, which eagerly cooperated with the United States.

Ivan was dispatched on several trips to the region, including a trip to Tajikistan, in which some of the basing issues were discussed with President Immoral Rakhmonov. ${ }^{8}$

Westernizes, such as the former Foreign Minister Andrei Kozyrev, have long called for U.S.-Russian cooperation in controlling the threats which emanate from Afghanistan and Central Asia: terrorism, drug trafficking, radical and militant brands of Islamic proselytizing. For years, American top policy makers, such as then-secretaries of state James Baker and Warren Christopher have not paid attention to Russia's pleas. ${ }^{9}$

However, as the U.S. started addressing issues of common concern, the usual suspects - inside-the-Moscow-Ring-Road experts, who express the frequent misgivings and phobias of Russia being mistreated by the U.S., continue to complain about the heightened U.S. presence in the post-Afghan war Central Asia. ${ }^{10}$ These are fears of Russia' imperial decline, which we have heard for the last twelve years, not really a concern about the U.S. unilateralism. In fact, factors which influence changes in the strategic and geopolitical power balance (what in the "good old days" Muscovites used to call "the correlation of forces,") go beyond the recent American military success where the Soviet Arms failed so abysmally only twelve years ago - Afghanistan. The timeframe of the balance of power shift is much wider, and its scope is truly global.

First, Moscow analysts see a connection between the martial feat of the Afghan war and the U.S. announced withdrawal. However, the roots are in the prevailing strategic analysis in Washington, not in the performance of the Green Berets in mountains of Torah Boar.

According to the thinking of the policy trio at the Pentagon: Secretary of Defense Donald Rumsfeld; Deputy Secretary of Defense Paul Wolfowitz, and Undersecretary for Policy Doug Feith, the ABM Treaty simply outlived the world for which it was designed. In 1972 there were two military superpowers:

\footnotetext{
${ }^{8}$ Russian minister to visit Tajikistan on 7 December, talk with Northern Alliance," BBC Monitoring Former Soviet Union - Political, 03:40, December 6,2001, quoting ITAR-TASS.

${ }^{9}$ Remarks by Andrey Kozyrev, the former foreign minister, a $t$ a breakfast of the American Chamber of Commerce in Russia. Federal News Service, April 2, 2002.

${ }^{10}$ Igor Torbakov "Russia Worries That Afghan Success Will Prompt US Unilateralism," Eurasia Net, January 2, 2002, http://www.eurasianet.org/departments/insight/articles/ eav010202.shtml
} 
the USSR, which invented and deployed its missile defense in the 1950s, and 60 s, and the U.S., which was mired in the morass of Vietnam. It took President Johnson many hours to convince then-Soviet Premier Alexei N. Kosygin to limit the deployment of the Soviet anti-ballistic missile shield to the capital city of Moscow.

Today, the situation is different: while Russia will enjoy an ICBM arsenal capable of penetrating any American strategic defenses in the foreseeable future, an attack originating from North Korea, Iran, Iraq or any other emerging nuclear power, may be thwarted by the new ballistic missile defense. Thus, Russia has not been denied the second-strike capability and does not lose its strategic parity with the United States.

Second, the prevailing Republican Party thinking on the ABM Treaty stems from President Ronald Reagan's idea of Star Wars and thus has internal partisan politics roots. Missile defense featured prominently on successive Republican Party platforms through the 1990s. Reagan, the spiritual leader of the current generation of Republicans and the most popular post-World War Two Republican president, has left the legacy of protecting American mainland from ballistic missile attack to those leaders who come after him. And Reagan has envisaged technology sharing and other cooperation in this area with Russia.

Thirdly, a liberal critic of the Russian policy with excellent ties to the upper echelons of the military establishment, Pave Felgengauer claims that Russia received a "slap in the face" from its American ally. If President Putting heard about Felgengauer's soundbite, he would have disagreed. His measured response indicates that Putin understands that the U.S. and Russia are facing the common enemy: global Islamist terrorism, which is not limited to Afghanistan.

The flames of jihad can be fanned in Northern Caucasus and even in the Volga valley by the same quarters that bankroll Usama bin Laden and Al-Qaeda network: by rich fundamentalists based in Saudi Arabia and the Gulf States.

As to Alexei Arbiter's well-known quote from Otto von Bismarck about international coalitions which consist of a mule and a rider - Russia, with its unique geographic span and clout in Central Asia is far from being a mule. In addition, when faced with a threat from a pack of wolves, riders and mules make excellent coalition partners indeed. Or, as my favorite Russian expression goes, "let's be friends - against whom?"

Fourth, and most importantly, Russia has been going through a decade of phantom pains of the amputated superpower. Today, it finally is getting over it. It starts to realize its real place in the world: that of a great power, but not of a 
superpower. It is true that its GDP, GDP per capita, population size, or even military prowess make it less intimidating or dominating than the USSR, that Stalin's equivalent of the Golden Horde. But it is for the benefit of the Russians. The costs of empire impoverished the ordinary Soviet men and women.

It is also true that while the United States brilliantly won two wars - the 1991 Gulf War and the current campaign in Afghanistan - Russia lost both its Afghan campaign and the 1994-1996 Chechen campaign. The outcome of the current Chechen operation is in doubt. The Russian army is not at the par with American military, primarily because over the last twelve years the Russian generals hopelessly bungled up their military reforms, and because a modern military is a very expensive, high tech proposition - a luxury only very rich can afford.

Still, the Moscow foreign policy establishment should not forget that Russia turned out to be more important for the United States in the war in Afghanistan than any of its NATO ally save Great Britain, and was second only to Pakistan in geopolitical importance. While the Russian forces did not fight in Afghanistan, neither did the French or the Germans. In fact, the U.S. turned down the unprecedented offer of assistance by NATO, not because of nonexistent unilateralism, but because of insufficient battlefield compatibility between cash-starved European militaries and the high-tech U.S. forces.

It still may come out that the Russian sestinas played a critical role in respelling the Northern Alliance in the early days of the war. Moreover, Washington insiders told Eurasia Net that US-Russian intelligence cooperation was exemplary - a great achievement after 80 years of rivalries between the Western and Russian spies.

After three years of economic growth, the Russians retain most of the gains of the post-Soviet era: freedom of speech, freedom of travel, a modicum of political and economic stability - and even some increased optimism, as measured by a flurry of recent public opinion polls.

They are gaining friends in Europe and the United States. And yes, they are treated as partners and on the same terms as others - just as President Putting requested (in relation to admittance to WTO). But being treated as partners also implies playing by partnership rules - not to supply weapons to Teheran's terror-mongering ayatollahs or provide the U.N. cover to the Butcher of Baghdad.

We should hail the U.S.-Russian security cooperation and prepare to difficult battles ahead against the common enemy. It is unseemly to poison these 
achievements by incessant whining about American unilateralism and mistreatment of Russia.

\section{Regional Powers}

China's balance of power crumbles. The military action in Afghanistan affected the future of the emerging Chinese Russian partnership in Central Asia and the Shanghai Cooperation Organization, which some feared would be a Chinese "co-prosperity zone" for Central Asia. The history of that organization made it clear that the post-Soviet Russia cannot carry alone the burdens of the regional superpower in Central Asia, and that China had to step in to do some of the burden-sharing. However, China is primarily preoccupied with its Pacific strategy and economic instability at home, as well as with the arduous postJiang succession. The leadership may not have time and resources to focus on Central Asia to make a difference.

After the U.S. operation in Afghanistan, Shanghai Six proclaimed their continues commitment to "combat the three evils: terrorism, religious extremism and ethnic separatism. ${ }^{11}$ " Geographically, the members of SCO are committed to fight separatism in Chechnya and North-Western China, and Islamic Movement of Uzbekistan (IMU). The member countries have committed to launch a joint anti-terrorism center in Bishkek, Kyrgyzstan.

However, little was accomplished to counter these militant Islamic organizations, such as the IMU and a larger Islamic party, Hizb-ut-Tahrir. The only noticeable development so far was a joint operation with participation of Russian, Chinese, and Kyrgyz forces to intercept radical groups which conducted kidnappings for foreigners in Kyrgyzstan in $1999 .{ }^{12}$ and prior to 9/11 President Karimov of Uzbekistan went out of his way to improve relations with Russia.

On the policy level, the SCO members voiced commitment to strengthening the administration of religious affairs, such as re-registering religious organizations and mosques; banning religious interference in politics; limiting prayer to mosques only (and not outside); and confining religious education to designated schools.

Other recommended measures included textbook revision; banning illegal groups which spread fundamentalism; preventing foreign clerics from conducting unauthorized missionary work; and stepping up anti-terrorist operations. ${ }^{13}$

\footnotetext{
${ }^{11}$ Jasper Becker and Agency France Press, "Shanghai Six target Muslim three," South China Morning Post, January 9, 2002.

${ }^{12}$ GAO Quaff, "Combating the Three Evil Forces," Beijing Review, www.bjreview.com.ch/ bireview/EN /200127/GlobalObserver-200127(A).htm

${ }^{13}$ Gao Quifu, "Combating the Three Evil Forces,"
} 
However, all these military and bureaucratic activities did not camouflage the fact that the leadership in Beijing did not expect such as massive demonstration of American military force halfway around the world. According to China military watchers, it has difficulty understanding, let alone catching up with the high-tech, wired U.S. military.

Geopolitically, the Chinese leadership saw years of work on the Central Asian China-led alliance go up in smoke - destroyed by the same people who brought down the World Trade Center.

In less than three months after $9 / 11$, China saw U.S. air bases springing in its back yard: in Afghanistan, Kyrgyzstan, and Uzbekistan. It saw an unprecedented improvement in the ties between its decades-old client Pakistan and Washington, as well as a rapprochement between the U.S. and the two largest China's neighbors: India and Russia. The Russian leadership under Putin made it clear that Russia views the United States and the West as the principal partners in the future, while expressions of unease about China has become more often and more clear among the Moscow political elite. While reunification with Taiwan and South China Sea strategy allegedly remains on the top of Beijing's geostrategic menu, the shift in the balance of power from China's point of view is pronounced. The dilemma: to fight international terrorism or to oppose the United States in the Pacific is not an easy one for China, and will continue to preoccupy the Beijing leadership in the years to come.

Iran, the anti-status quo power: The bifurcated regime in Tehran, which consists of elected Muslim moderates and unelected anti-American hard-liners, has initially voiced support for the U.S. operation in Afghanistan, but within a week, the Supreme Leader Ayatollah Ali Khomeini had signaled the return of anti-American rhetoric. This was followed by a call from the former president and the Chairman of the powerful Guardians' Council Hashemite Rafsanjani to use nuclear weapons to destroy Israel - hardly a statement of peace and cooperation. However, the immediate concerns of the Iranian leadership are connected to the growing U.S. power in the region.

According to a senior U.S. security official who recently spoke on the condition of anonymity in Washington, D.C., Iranian "non-elected" branch of the government allowed hundreds of Al Qaeda fighters to escape Afghanistan, and supported anti-Kara militias in their attempts to upset the precarious postwar balance of power.

Recent developments indicate that stabilization efforts in Afghanistan remain fragile, and the pro-U.S. Karzai administration, precarious. Afghan security 
forces on April 3 arrested dozens of suspects who allegedly conspired to overthrow Karzai's interim government.

The same senior Bush Administration official, supported an earlier Afghan assessment that exiled warlord Gulbuddin Hekmatyar, along with the "nonelected" part of the Iranian leadership, were behind the coup attempt.

The incident is prompting US officials to concentrate on training programs designed to enhance security conditions in Afghanistan. The twin priorities for Washington over the near- and medium-term are the convocation of a successful Loyal Jirga, or grand tribal council, and improvements in Afghan military and security services capacity. The Loyal Jirga is expected to convene in June to establish the framework for the country's future political system.

At the same time, the Bush Administration official suggested Iran posed a threat to security over the near term. "Tehran allowed safe passage to hundreds of al Qaeda," the official said. "They allowed senior Taliban leaders to escape or are supporting them today. Tehran has sent arms, operatives, large amounts of cash, and even TV and radio equipment.

"They are positioning assets and people for future contingencies. They (...) are building relationships for the long term," the official continued. "They feel insecure and fear a US encirclement. The insufficiently Islamic nature of the present Afghan regime makes the Iranians nervous. Our bases in Central Asia and Turkey make them nervous. And they take seriously the Bush Administration's desire to see Saddam gone. If Iraq changes, so might Iran. ${ }^{14}$

\section{Geo-economics}

The "peace dividend" of the U.S. operation in Afghanistan is slow to materialize. Western and local businesses did not announce hardly any new projects. Besides the renewed rumors of building an oil and gas pipeline from Turkmenistan (with a possible branch from Uzbekistan), to Pakistan and India, few hopeful developments were reported. The California-based UNOCAL and the Saudi Delta were two companies which examined the feasibility of such a pipeline, and even invited the Taliban officials to visit the U.S. West Coast in 1996.

Journalists often derisively referred to the pipeline from Central Asia to the Indian subcontinent as the pipeline "from hell to hell, through hell." Today, the political risk outlook for the Ashgabat-Kabul-Delhi pipeline has improved. However, most analysts agree that until such time that Afghanistan is pacified and stable, the political risk of such venture will be too high.

Moreover, the main target market for Central Asian hydrocarbons is India, not Pakistan, but it is impossible to build such a pipeline without going through

\footnotetext{
${ }^{14}$ Ariel Cohen, “Washington Fears for Karzai's Future,” EurasiaNet, April 9, 2002,
} 
Pakistan. And the relationship between the two nuclear neighbors remained tense. Until such time that the Delhi-Islamabad ties improve, it is unlikely that energy companies would be interested in pouring billions of dollars into a pipeline which may be shut down because of tensions.

Finally, the pipeline would politically benefit the dictatorial regime of President Saparmurad Niyazov, self-nicknamed Turkmenbashi, and the leader of Turkmen; however, the U.S. and Russia have deep misgivings about the nature of his regime and its role of friendly neutrality towards both the Taliban and Tehran. Accusations of arms smuggling and facilitation of drug trafficking have come out as several high level Turkmen officials, including the former Foreign Minister Boris Shikhmurardov, and security chiefs have defected. As long as Turkmenbashi is power, it is likely that Washington and Moscow may impose a political veto which will prevent the pipeline from being constructed.

\section{Conclusion}

The challenges of enhancing security, controlling Islamic extremism, and building the civil society which allows for sustainable development and human rights, remain dire, less than a year after September 11 attacks. The military component of the U.S. power projection into a previously neglected region is impressive.

Washington now recognizes that in the past Central Asian countries lacked the "southern option" - a network of roads, railroads and pipelines to markets of Pakistan and India, and access to the global markets through the Indian Ocean. As the increased attention on the southern option suggests, economic development is playing an increasing role in Washington's thinking about the future of Afghanistan. Accordingly, the Bush Administration intends to invigorate follow-up to the January donor summit in Tokyo, where over $\$ 3.8$ billion in aid was pledged. So far, not much financial assistance has been delivered to Afghanistan.

The Administration faces difficult choices as to whether - and to what extent -it should support authoritarian regimes in Uzbekistan, Kyrgyzstan, Kazakhstan and elsewhere in the region. While immediate military contingencies are dictating closer ties, long term planning may advise caution: As the Soviet-era elites, with their common communist experience are aging, it is not clear what will be the nature of the new, emerging leadership.

Ultimately, the regional balance of power is likely to be more skewed towards the United States, with Russia playing an important, albeit a supportive role. At least some decision makers in the Bush administration believe that its policy towards Central Asian states will be more coordinated with policies towards Iran and Afghanistan. 